\title{
Students' Attitudes in Colleges of Education at the Jordanian Universities towards Mobile Phone Usage in University Education
}

\author{
http://dx.doi.org/10.3991/ijim.v7i2.2286 \\ Jebreen A.Hussain ${ }^{1}$, Khalid Al-Qudah ${ }^{2}$, Reem Al Matari ${ }^{1}$ \\ ${ }^{1}$ Hashemite University, Zarqa', Jordan \\ ${ }^{2}$ Al al-Bayt University, Mafraq, Jordan;
}

\begin{abstract}
The aim of this study was to investigate the students' attitudes in the colleges of education at the Jordanian universities toward the use of mobile phones in education, according to the University which is attended by the student, gender, and academic level of the student. The study sample consisted of (363) students selected randomly from the colleges of education at the Jordanian universities: The Hashemite University, Yarmouk University and University of Jordan for the academic year 2010-2011. The instrument was a questionnaire developed by the researchers. The results showed that the percentage of students who indicated positive attitudes towards mobile phone use in university education is high. The results also showed that there were significant differences in the attitudes of students of the colleges of education in Jordanian universities towards mobile phone use attributed to the variable of the university and in favor of the Hashemite University. The results showed no significant differences in students' attitudes toward mobile phone use in university education attributed to gender. Findings also revealed that their presence of statistically significant differences in students' attitudes toward mobile phone use in university education attributed to the variable of academic level in favor of MA students.
\end{abstract}

Index Terms-Students' attitude, mobile phone usage, education

\section{INTRODUCTION}

Contemporary communities face many challenges and their impact on the nature and the style of life and the various organizations. The most prominent challenges are represented in the progress of information technology and modern communication which contributed to radical change in the nature of life and the form of the educational institutions. (Kafafi, 2007).

The educators tried to adapt to these changes in the teaching and learning process in terms of objectives, methods and experiences, and in terms of learning resources and educational and assessment competencies. In the light of these developments, the educators dedicated time and efforts to use the latest technology to improve the vision of the future of education and established a model of the technological applications to promote the educational attitudes to achieve effective learning which fosters creativity and inculcate the moral values and the positive trends, and to keep pace with the technological innovations and develop the educational process (Al Omari, 2008, Ascough, 2002).
This change in the teaching and learning strategies led to the emergence of a new philosophy in education which was given similar names such as e-learning and distance learning in terms of dealing with the computer, the internet and the information systems. (Khan, 1997 and Volery, 2000).

A few years ago and specifically in the beginning of the twenty first century a new term in the educational field was used in English " Mobile learning" In Arabic it is called mobile learning. Mobile learning is defined as the learning achieved by using small mobile electronic devices such as smart phones, personal digital assistants "PDAs" and other similar portable devices. (Mcconatha and Praul, 2008). Mobile learning is considered a new form of distance learning which began to develop since the eighties of the twentieth century from learning by correspondence to the use of the latest media technology in education ( $\mathrm{Al}$ - Fahad, 2009). E-learning has provided distance learning with new learning methods based computers and computer network technology. Wireless and network technology can provide important learners opportunities for individual whose areas infrastructure needed for e-learning for all who wish to learn. (Hammamy, 2006).

The idea of the mobile phone was inspired by the idea of radio .The researchers found that it was possible to develop a new technology to send and receive data through frequencies that can be used several times by compressing data and send them through very short time units to make several phone calls simultaneously. This technology is based on a basic unit called cell, which is in its turn is considered a part of the mobile network system. There are two types of networks:

- Wireless Personal Area Network (WPAN) consisted of wireless connections between several networks within short distances (several meters) by using the computer in most cases.

- The Wireless Local Area Network (WLAN) -is designed for the local network in companies, homes, and public places. All devices within the range of WLAN can communicate with each other. (Salem, 2006).

Some people believe that wireless technology is the same mobile wireless technology. (Cook, Pacher \& Bradlen, 2008) except that wireless technology is different from the mobile technology. (Malady and Agrawal, 2000) think that mobile wireless technology consists of two 
parts: computer and mobile which provide the learner access to various information networks without abiding by the limits of time and place.

Wireless technology means transferring any form of data ( text- voice - image - motion - video ) through radio wave infra red rays and microwave . (Dubendorf, 2003).

Mobile phone technology renders several services including:

- SMS (Short Message Service).

- WAP (Wireless Application Protocol)

- GPRS(General Packet Radio Service )

- MMS (Multiple Listing Service)

Other types of mobile phones include personal digital assistants (PDAs). (PDAs) are laptop computer carried by hand or can be inserted in the pocket designed initially for use in organizing personal appointments, storing friends' phone numbers and their addresses, recording private data and writing down notes during lectures or meetings and lists of tasks.

With time, these devices were developed into minicomputers which run text editing programs and spreadsheets. With the advent of a new generation of these devices and being popular among people, mobile phone developed and rendered new services such as wireless phone communication, downloading audio and video files and connection to internet and downloading and reading e-books and reading e-mail by using wireless modem devices (Salem, 2006).

From a technical perspective, the mobile technologies such as mobile phones, computers, and personal digital devices are sold now for reasonable prices than ever before, and the numbers of the personal devices connected to the internet are used by large numbers of people. (Dahshan, and Younus, 2009).

The use of mobile phones as an integrated part of educational technology indicates major changes in education which would free the teacher and the student form the constraints of the traditional education and provide the opportunity for human interaction to take place between them. Hence, the need for the introduction of mobile phones in university instruction is urgent and necessary.

The necessity to use mobile phones in education seems imperative and inevitable. Therefore, preparedness for using this technology in university education should be based on the concept of conviction and acceptance to use it in the teaching learning process. Positive attitudes towards using this technology in university education should be formed and established. Positive attitudes towards instructional material lead to more achievement than learning directed to gain only knowledge because students are expected to forget knowledge based on remembering. (Husain, 2011).

Forming positive attitudes towards education increases the desire of the student in learning and improves his (her) ability to apply what he/she learns. (Mohammad \&Alkaraki, 2008). Low student achievement in education can be attributed to their negative attitudes towards the instructional materials and the associated hatred and frustration, and these conclusions apply also to the university students. (Keegan, 2010)

Many studies emphasize that the positive attitudes towards using the new technologies such as the mobile phone in education is associated with better achievement than negative attitudes. This study is an attempt to identify the attitudes of the students of the colleges of education at the Jordanian universities towards the use of the mobile phone in university education in the light of some variables.

\section{Research Problem}

Mobile phone have spread among large numbers of people, especially university students. The Jordanian universities are competing to adopt e-learning and communication media in education since the traditional learning no longer meets the needs of the contemporary society. The universities have to make advantage of the potential applications of the mobile phones in higher education. Availability of mobile phones contributes to the development of the human resources and the local community. Thus, the universities have to provide special environment to make use of the mobile phones in developing the students' capabilities in education and giving them the opportunity and access to the new innovations to reach a high level of excellence and creativity. Students are the centre of the educational process. So it is necessary to identify their attitudes towards using mobile phones in education. Hence the problem of the study is to identify the attitudes of the students at the colleges of education at the Jordanian universities towards mobile phone usage in education and to identify the effect of the variables: university, gender and the academic level of the student on those attitudes. Therefore, the study is an attempt to answer the following questions:

1. What are the attitudes of the students of the colleges of education at the Jordanian universities?

2. Are there significant statical differences among the students' attitudes towards mobile phone usage in education attributed to the university (The Hashemite, University of Jordan, Yarmouk )?

3. Are there significant statistical differences among the students' attitudes towards mobile phone usage in education attributed to the gender of the student?

4. Are there significant statistical differences among the students' attitudes towards mobile phone usage in education attributed to theacademic level of the student?

\section{SIGNIFICANCE OF THE STUDY}

Significance of the study stems from the importance and wide usage of the mobile phones among students .Identifying the students' attitudes towards its use in education and the information and data which this study is going to provide .Decision makers can benefit from such data and information and can foster the positive attitudes of the students and develop their attitudes. This will lead to good choice of the methods and activities which encourage students to use mobile phone in education in the future.

The results of this study may also contribute to the literature review with a study of great scientific value among the studies that dealt with using educational technology in university education.

The results may also introduce the potential usage of mobile phone in education, in training students and restructuring the policies of higher education ,including curriculum, and mobile learning. The significance of the study is emphasized by the instrument of the study devel- 
oped by the researchers that can be used in other subsequent studies. It is expected that graduate students and educational researchers, who are interested in applying advanced technology in higher education may benefit from it.

\section{LiMitATiONS OF THE STUDY}

The results of the study can be generalized in the light of the following limitations:

1. The measuring instrument was developed by the researchers, so the results of this study depend on its validity and reliability.

2. This sample of the study consisted of the students of the colleges of education at the Jordanian universities. (Hashemite, University of Jordan and Yarmouk).

3. To apply the results of this study outside the population of the study is determined by the similarity of the outside community to the population of the study.

\section{Operational DeFinitions:}

- Mobile Phone: It is a wireless communication device regardless of its type, uses and services.

- Mobile Phone usage in education: Using and applying the mobile phone in the educational process such as sending text messages, social communications between the student and the teacher or among students themselves.

- The attitudes toward the use of the mobile phone in education: They are the feelings, prejudices, ideas, and inclinations of the students towards the use of mobile phones in education. The attitude is measured by the mark obtained from the students' responses to the items of the instrument of the study. For the purpose of the study, the researchers will consider the student who gets (150) out of (250) that is $60 \%$ or more a student with a positive attitude, and the student who gets less than (150) or less than $60 \%$ is a student with negative attitude towards the use of mobile phone in education.

\section{PreVious STUdies:}

Many studies were conducted about the use of mobile technologies in education, and the students' attitudes toward them.

AL-Fahad (2009) conducted a study to identify the female students at King Saud University in Saudi Arabia towards the use of the mobile phone in education. The sample of the study consisted of (186) female undergraduate students majoring in arts and medicine. The researcher used a questionnaire as instrument for his study. The results indicated the students' preference for using the mobile phone in their learning regardless of time and place. The mobile phone enabled them to communicate easily with each other, and to exchange information and data related to their instructional materials.

Al-Qudah (2008) conducted a study aimed to identify the ownership and usage of mobile phones among university students in Jordan. It also aimed at revealing any significant statistical differences among students' ownership and usage, which may be attributed to gender, age, type of university, type of college and level of academic program. The sample of the study consisted of (993) students chosen randomly from nine public and private universities in Jordan in 2006/2007. The instrument was a questionnaire developed by the researcher. Results show that $87.2 \%$ of the respondents own mobile phones. Significant differences are revealed among respondents' ownership ( $\alpha \leq 0.05)$ attributed to the following variables: gender, in favor of males; age, in favor of (24-26) and $(27+)$ age brackets, the type of the college, in favor of colleges of sciences; and the level of the academic program in favor of the masters' level. Significant differences are also revealed among the respondents' personal and social usages $(\alpha \leq 0.05)$ attributed to the following variables: gender, in favor of males; age, in favor of (18-20) and $(27+)$ age brackets, and type of university, in favor of public universities. Significant differences are also demonstrated among students' educational usage attributed to gender, in favor of males; age in favor of (18-20) and (2123) age brackets; type of university, in favor of the public universities, and the type of college in favor of colleges of science.

Maecconath and Lynch (2008) conducted a study to investigate the extent of mobile phone use in university education at the University of Thornhurst in USA. The sample of the study consisted of (1128) students who studied social studies course. The sample was divided into two groups. One group studied the course by using the mobile phone, and the other group studied it without the mobile phone. The results indicated that the students who studied by using the mobile phone achieved higher than the other group.

Tennant (2008) and Dong and Agogino (2004) conducted studies on the usefulness and effectiveness of personal digital devices and mobile phone in the educational process and the preference of the learners in the learning process. The results of the study indicated that this technology enriches the students learning dramatically through the exchange of information and experiences among themselves.

Kook (2007) conducted a study on a sample of (91) students who studied a course. He used a questionnaire to measure the effect of the mobile phone in stimulating motivation towards learning. The results indicated that their motivation increased towards learning the more they used the mobile phone in education, and they preferred the mobile phone in education.

Pachler (2007) thinks that using the mobile phone in education supports the innovative education and develops the students' activities and strengthens the spirit of research. Mobile phone in education is characterized by flexibility, interaction and communication between the teacher and the student.

Waycott and Kukulsca-Hulme (2003) conducted a study on the role played by mobile phone and PDAs in student learning and the impression the students got about them. The results of the study were less than expected by the researchers the students faced a difficulty in retaining the sent and exchanged data by these devices. Some students could not make notes easily as in the case of using paper materials in their traditional learning.

The previous studies can be categorized as follows:

- Studies indicated positive impact of using the mobile phone in education, such as :( Al-Qudah, 2008), (Tennant, 2008), (Pachler, 2007), (Kook, 2007), (Al- 
Fahad, 2007), (Kukulaska-Hulme, Traxler, 2006) and (Dong and Agogino, 2004).

- Studies indicated effectiveness of the mobile phone in education and an increase in students' achievement, such as: (Dong and Agogino, 2004), (Pachler, 2007), (Tennant, 2008) and (Macconth and lynch, 2008).

- A study indicated the difficulty in using a mobile phone in education, (Waycott and Kukulsca Hulme, 2003).

This study differs from the previous studies in its use of several variables such as: the academic level, the university. The population and the sample of study are also different and they focus on the attitudes of the students towards this new technology. The present study has benefited from those studies in the general theoretical framework and building the items of the instrument and benefited from the results of some studies in interpreting the results of the present study.

\section{RESEARCH METHOD AND PROCEDURES}

\section{A. Methodology of the Study:}

The descriptive survey method was adopted in conducting this study. The descriptive analysis was used in analyzing the data of the study. The means, standard deviations, t-test, analysis of variance in analyzing data were used (SPSS).

\section{B. Sample of the Study:}

The study sample consisted of (363) students from the colleges of education in Hashemite, Yarmouk and University of Jordan for the academic year 2010/2011 who were randomly chosen.

Table (1) shows the distribution of the study sample according to the study variables and levels.

TABLE I.

THE STUDY SAMPLE DISTRIBUTION ACCORDING TO THE VARIABLES OF THE STUDY.

\begin{tabular}{|c|c|c|c|c|c|}
\hline \multicolumn{4}{|c|}{ University } & Gender & Variable \\
\hline University of Jordan & Yarmouk & Hashemite & Female & Male & Level \\
\hline 126 & 122 & 115 & 284 & 79 & Number \\
\hline $34.7 \%$ & $33.6 \%$ & $31.7 \%$ & $78.2 \%$ & $21.8 \%$ & Percentage \\
\hline
\end{tabular}

\section{Instrument of the Study:}

The researchers reviewed the literature review and many attitude measures such as (Mohammad et. al 2008; Abuloum \& Al- Kadash, 2005, Oreiqat, 2003).An open questionnaire about the mobile phone and its applications and uses in education was distributed to the sample. A special measure has been built and developed to measure the student's attitudes towards using the mobile phone in education. The instrument consisted of (50) items, (33) items were positive and the other (17) items were negative according to Likert scale with five degrees. The positive items were ordered as follows: Strongly agree, agree, unsure, disagree, and strongly disagree $(5,4,3,2,1)$. The negative items were ordered as follows : strongly disagree , disagree , unsure , agree , strongly agree $(1,2,3,4,5)$. See appendix (1).

\section{1) Validity of the Instrument:}

Initially, the instrument consisted of (62) items and was reviewed by group of (15) judges from the faculty members of the Jordanian universities who hold doctoral degrees in education and information technology, curriculum and instruction, and psychology. They were asked to give their opinions of the appropriateness of the items of the instrument to measure what they have been designed for. They were also asked to check the language of the items and clarity of their meaning, and to delete or modify any items as they perceive. In the light of the suggestions of the judges, some items were modified and some items were deleted. The final copy of the instrument consisted of (50) items.

\section{2) Reliability of the Instrument:}

The instrument was applied to an exploratory sample consisted of (90) students chosen from outside of the sample of the study. The instrument was applied again after three weeks to the same exploratory sample. Pearson coefficient was calculated and the coefficient reliability of the whole instrument was (0.86). This value was considered appropriate for the purposes of the study. Split - half method was calculated for the whole performance of the sample of the study and was (0.89). Cronbach alpha equation was applied and the reliability coefficient for the internal consistency was calculated and was found (0.88). This value was considered appropriate for the purposes of the study.

3) Research Procedures:

1. The instrument of the study was prepared by using the literature review and the previous studies and the opinion polls on the World Wide Web.

2. The instrument was reviewed by a group of judges.

3. The questionnaire was distributed to the classes which include both bachelor and masters students during lectures and was retrieved also by land.

4. The questionnaire was distributed to an exploratory sample outside the study sample and was reapplied after three weeks to the same exploratory sample.

5. The completed questionnaires were collected and the data were treated and analyzed to obtain the results.

D. The Study Variables:

1) The Independent Variables:

1. The university, which is attended by the student, and has three categories :

- University of Jordan.

- The Hashemite University.

- Yarmouk University.

2. The gender of the student which has two categories:

- Male.

- Female.

3. The academic level which has two categories :

- Bachelor.

- Masters.

\section{2) The Dependent Variable:}

the students' attitudes in colleges of education at the Jordanian universities towards the mobile phone use in university education. 


\section{THE RESULTS OF THE STUDY:}

\section{A. Results Related to the First Question}

What are the students' attitudes in the colleges of education at the Jordanian universities towards the use of the mobile phone in university education?

To answer this question, the means and the standard deviations of the students' attitudes towards the mobile phone usage in university education has been calculated. Table II shows that.

Table II: indicates that the means, the standard deviations and the percentage of the questionnaire items positive attitudes of the students towards the mobile phone usage in university education.

The percentages of (34) items were above $60 \%$ and the percentages of (16) items were below $60 \%$ which indicate that the students' attitudes were positive towards the mobile phone usage in university education.

The percentages of eight items were above $80 \%$. (Items $26,2,24,37,8,7,10$, and 20). The item which obtained the highest percentage $(89.4 \%)$ was: (I like to use the mobile phone because it connects me with any person at any time and wherever he is). The item which says (The use of the mobile phone for educational purposes, requires good planning and proper preparation) got (85\%) percentage. The item which came third in order which says: (It is useful to use the mobile phone on the personal level.) got (84.2) percentage. Item number (20) which came fourth in order (The practice of using the mobile phone is an easy process.) got $(80.6 \%)$ percentage. Item number (21) got the highest percentage among the following items $(25,4,1,3,9,50,16,45,23,34,35,47,49,36,38,17,32,41,5)$ and got a percentage of (77.8\%) Item 21 says :( I encourage my colleagues to use the mobile phone for educational purposes).It is followed by item (25) which says :( Using the mobile phone provides valuable information.) and got a percentage of $(77.6 \%)$ ).Item (5) which says (I hope that the faculty members communicate with their students for educational purposes.) got a percentage of (70.8\%). Five items $(27,31,13,15$ and19) got percentage between (63\%- 69.6\%). Item (27) which says: (I think we will be forced to use mobile phones in university education in the future.) got (69.6\%) percentage.Item (31) which says: (I tend to generalize the use of mobile phones in education as it revolutionizes the world of education .) got a percentage of $(67.4 \%)$. Item (19) which says: (Mobile phone usage consumes a lot of time) got the lowest percentage in this group $(63 \%)$.

The percentages of eleven items were below $60 \%$ and were between $(50 \%-58.6 \%)$. The number of those items $(42,21,14,29,43,11,30,22,6,39$, and 12). Item number (42) which says :( I think that the use of mobile phones is devastating the human values.) got the highest percentage among this group (58.6\%) followed by item (21) which says :(mobile phone usage in university education does not worth cost .) got a percentage of (58\%) . then the item which says :(It is difficult to develop effective teaching methods by using the mobile phone ) got a percentage of (57 .6 \%) .Item (12) which says: (I need more convincing reasons to use mobile phones in university education.) got percentage of $(50 \%)$. Five items got percentages between (45.6\%-49.4\%). Those items were $(40,22,28,48$, and 18) Item (40) which Says: (I think evaluation of the mobile phone usage in education cannot be carried out.)
TABLE II.

THE MEANS AND THE STANDARD DEVIATIONS OF THE STUDENTS' ATTITUDES TOWARDS THE MOBILE PHONE USAGE IN UNIVERSITY EDUCATION.

\begin{tabular}{|c|c|c|c|c|}
\hline $\begin{array}{l}\text { Number } \\
\text { of Item }\end{array}$ & Mean & $\begin{array}{l}\text { Standard } \\
\text { Deviation }\end{array}$ & Percentage & $\begin{array}{c}\text { Order of } \\
\text { Item }\end{array}$ \\
\hline 26 & 4.47 & 0.92 & 89.4 & 1 \\
\hline 2 & 4.25 & 0.855 & 85 & 2 \\
\hline 24 & 4.21 & 0.966 & 84.2 & 3 \\
\hline 37 & 4.08 & 0.986 & 81.6 & 4 \\
\hline 8 & 4.06 & 1.037 & 81.2 & 5 \\
\hline 7 & 4.04 & 0.932 & 80.8 & 6 \\
\hline 10 & 4.04 & 1.076 & 80.8 & 7 \\
\hline 20 & 4.03 & 1.008 & 80.6 & 8 \\
\hline 4 & 3.89 & 0.978 & 77.8 & 9 \\
\hline 25 & 3.88 & 1.056 & 77.6 & 10 \\
\hline 1 & 3.87 & 0.959 & 77.4 & 11 \\
\hline 3 & 3.87 & 0.987 & 77.4 & 12 \\
\hline 9 & 3.81 & 1.155 & 76.2 & 13 \\
\hline 50 & 3.75 & 1.081 & 75 & 14 \\
\hline 16 & 3.74 & 1.013 & 74.8 & 15 \\
\hline 45 & 3.74 & 1.028 & 74.8 & 16 \\
\hline 23 & 3.73 & 1.137 & 74.6 & 17 \\
\hline 33 & 3.73 & 1.125 & 74.6 & 18 \\
\hline 34 & 3.73 & 1.019 & 74.6 & 19 \\
\hline 35 & 3.71 & 1.107 & 74.2 & 20 \\
\hline 47 & 3.68 & 1.188 & 73.6 & 21 \\
\hline 49 & 3.68 & 1.037 & 73.6 & 22 \\
\hline 36 & 3.65 & 1.083 & 73 & 23 \\
\hline 38 & 3.64 & 1.134 & 72.8 & 24 \\
\hline 46 & 3.64 & 1.048 & 72.8 & 25 \\
\hline 17 & 3.62 & 1.024 & 72.4 & 26 \\
\hline 32 & 3.62 & 1.087 & 72.4 & 27 \\
\hline 41 & 3.58 & 1.149 & 71.6 & 28 \\
\hline 5 & 3.54 & 1.277 & 70.8 & 29 \\
\hline 27 & 3.48 & 1.091 & 69.6 & 30 \\
\hline 31 & 3.37 & 1.086 & 67.4 & 31 \\
\hline 13 & 3.30 & 1.098 & 66 & 32 \\
\hline 15 & 3.29 & 1.126 & 65.8 & 33 \\
\hline 19 & 3.15 & 1.272 & 63 & 34 \\
\hline 42 & 2.93 & 1.179 & 58.6 & 35 \\
\hline 21 & 2.90 & 1.124 & 58 & 36 \\
\hline 14 & 2.88 & 1.113 & 57.6 & 37 \\
\hline 29 & 2.78 & 1.183 & 55.6 & 38 \\
\hline 43 & 2.77 & 1.167 & 55.4 & 39 \\
\hline 11 & 2.73 & 1.252 & 54.6 & 40 \\
\hline 30 & 2.72 & 1.126 & 54.4 & 41 \\
\hline 44 & 2.69 & 1.214 & 53.8 & 42 \\
\hline 6 & 2.52 & 1.057 & 50.4 & 43 \\
\hline 39 & 2.52 & 1.150 & 50.4 & 44 \\
\hline 12 & 2.50 & 1.167 & 50 & 45 \\
\hline 40 & 2.47 & 1.080 & 49.4 & 46 \\
\hline 22 & 2.45 & 1.144 & 49 & 47 \\
\hline 28 & 2.40 & 1.114 & 48 & 48 \\
\hline 48 & 2.35 & 1.171 & 47 & 49 \\
\hline 18 & 2.28 & 1.162 & 45.6 & 50 \\
\hline
\end{tabular}

got $(49.4 \%)$ percentage followed by item (22) which says :( I think the use of mobile phone in education is financially costly) got (49\%) percentage. Item (18) which says :( I hate using the mobile phone in university education because I do not know how to use it) got the lowest percentage in this group $(45.6 \%)$. 


\section{B. Results Related to the Second Question}

Are there significant statistical differences among the students' attitudes in the colleges of education at the Jordanian universities towards the mobile phone usage in education attributed to the university (The Hashemite University, Yarmouk, and University of Jordan)?

To answer this question, the means, the standard deviation and one Way ANOVA were used to analyze the data Table III shows these results.

TABLE III.

MEANS AND STANDARD DEVIATIONS OF THE STUDENTS' ATTITUDES IN COLLEGES OF EDUCATION AT THE JORDANIAN UNIVERSITIES TOWARDS THE MOBILE PHONE USAGE IN UNIVERSITY EDUCATION ATTRIBUTED TO THE UNIVERSITY VARIABLE

\begin{tabular}{|c|c|c|c|}
\hline University & Number & Means & $\begin{array}{c}\text { Standard } \\
\text { deviation }\end{array}$ \\
\hline The Hashemite University & 115 & 3.48 & 0.421 \\
\hline Yarmouk University & 122 & 3.41 & 0.398 \\
\hline University of Jordan & 126 & 3.30 & 0.432 \\
\hline Total & $\mathbf{3 6 3}$ & $\mathbf{3 . 4 0}$ & $\mathbf{0 . 4 2 3}$ \\
\hline
\end{tabular}

Table III Indicates that the mean of the Hashemite University was (3.48), the mean of Yarmouk University was (3.41) and the mean of the University of Jordan was (3.30). The total mean of the three universities was (3.40) .To identify whether there are significant statistical differences among those means One- way ANOVA analysis was calculated. Table IV shows the results.

TABLE IV.

ONE-WAY ANOVA ANALYSIS OF THE EFFECT OF THE UNIVERSITY VARIABLE ON THE STUDENTS' ATTITUDES IN COLLEGES OF EDUCATION AT THE JORDANIAN UNIVERSITIES TOWARDS THE MOBILE PHONE USAGE IN UNIVERSITY EDUCATION

\begin{tabular}{|c|l|l|l|l|l|}
\hline $\begin{array}{c}\text { Source of } \\
\text { variation }\end{array}$ & $\begin{array}{c}\text { Average } \\
\text { sum of } \\
\text { squares }\end{array}$ & $\begin{array}{c}\text { Degrees } \\
\text { of } \\
\text { freedom }\end{array}$ & $\begin{array}{c}\text { Mean } \\
\text { of } \\
\text { squares }\end{array}$ & $\begin{array}{c}\text { F } \\
\text { value }\end{array}$ & $\begin{array}{c}\text { Statistical } \\
\text { signifi- } \\
\text { cance }\end{array}$ \\
\hline University & 2.108 & 2 & 1.054 & 6.040 & $0.003^{*}$ \\
\hline Error & 62.809 & 360 & 0.174 & & \\
\hline Total & 46.917 & 362 & & & \\
*significant at the level $(\alpha \leq 0.05)$
\end{tabular}

Table IV shows that there are significant statistical differences at the significance level $(\alpha \leq 0.05)$ among the students' attitudes in the colleges of education at the Jordanian universities towards the use of the mobile phone in university education attributed to the university variable in favor of the Hashemite University where $f$ value was (6.040) which means it is significant at a level below $(\alpha \leq 0.05)$.

To test the differences between the means according to the university variable Scheffe test for post-comparisons was used. Table V shows the results.

Table $\mathrm{V}$ shows that the difference among the means of university variable levels of the students' attitudes were statistically significant at the significance level $(\alpha \leq 0.05)$ in favor of the Hashemite university compared to the University of Jordan where the mean of the Hashemite university is (3.48) compared to the mean of the University of Jordan (3.30). This means that the attitudes of the students of the Hashemite University towards the mobile phone usage in university education are more positive than their colleagues at the University of Jordan.

TABLE V.

THE RESULTS OF POSTERIOR COMPARISONS BETWEEN THE MEANS OF THE STUDENTS' ATTITUDES IN THE COLLEGES OF EDUCATION AT THE JORDANIAN UNIVERSITIES TOWARDS THE MOBILE PHONE USAGE IN UNIVERSITY EDUCATION ATTRIBUTED TO THE UNIVERSITY VARIABLE

\begin{tabular}{|c|c|c|c|c|}
\hline \multirow{2}{*}{ University } & $\begin{array}{c}\text { The Hashemite } \\
\text { University }\end{array}$ & $\begin{array}{c}\text { Yarmouk } \\
\text { University }\end{array}$ & $\begin{array}{c}\text { University } \\
\text { of Jordan }\end{array}$ \\
\cline { 2 - 5 } & Mean & 3.48 & 3.41 & 3.30 \\
\hline $\begin{array}{c}\text { Hashemite } \\
\text { University }\end{array}$ & 3.48 & & & $*$ \\
\hline $\begin{array}{c}\text { Yarmouk } \\
\text { University }\end{array}$ & 3.41 & & & \\
\hline $\begin{array}{c}\text { University } \\
\text { of Jordan }\end{array}$ & 3.30 & & & \\
\hline
\end{tabular}

\section{Results Related to the Third Question}

Are there significant statistical differences among students' attitudes in the colleges of education at the Jordanian universities to towards the mobile phone usage attributed to gender?

To answer this question, the mean and t-test were used to identify the attitudes of the students in the colleges of education at the Jordanian universities towards the mobile phone usage attributed to gender. Table VI shows the results.

TABLE VI.

THE MEANS, STANDARD DEVIATIONS AND T-TEST OF THE STUDENTS' ATTITUDES IN THE COLLEGES OF EDUCATION IN THE JORDANIAN UNIVERSITIES ATTRIBUTED TO GENDER.

\begin{tabular}{|c|c|c|c|c|c|}
\hline Gender & Number & Mean & $\begin{array}{c}\text { Standard } \\
\text { deviation }\end{array}$ & t-value & $\begin{array}{c}\text { Level of } \\
\text { significance }\end{array}$ \\
\cline { 1 - 4 } Male & 79 & 3.42 & 0.418 & \multirow{2}{*}{0.654} & \multirow{2}{*}{0.980} \\
\cline { 1 - 4 } Female & 284 & 3.39 & 0.425 & & \\
\hline Total & 363 & 3.41 & 0.421 & & \\
\hline
\end{tabular}

Table VI shows that there are no significant statistical differences at the significance level $(\alpha \leq 0.05)$ among students attitudes in the colleges of education in the Jordanian universities towards the mobile phone usage attributed to gender, as the $(\mathrm{t})$ value is $(0.654)$ and the level of significance is $(0.980)$.

\section{Results Related to the Forth Question}

Are there significant statistical differences among students' attitudes in the colleges of education in the Jordanian universities towards the mobile phone usage attributed to the academic level (bachelor, masters)?

To answer this question, the means and the t-tast were used to identify the differences among students' attitudes in colleges of education in the Jordanian universities towards the mobile phone usage attributed to the academic level. Table VII shows the results.

Table VII shows that there are significant statistical differences at the significance level $(\alpha \leq 0.05)$ among students' attitudes in the colleges of education towards the mobile phone usage attributed to the academic level in favor of the master degree students with a mean of (3.55) compared to the undergraduate students with a mean of ( 3.38). The calculated value of $(\mathrm{t})$ value was(2.437-) and 
significance level $(0.015)$ which means that the attitudes of the master degree students in the Jordanian universities towards the mobile phone usage in university education are higher and more positive than the attitudes of the bachelor degree students.

TABLE VII.

THE MEANS, STANDARD DEVIATIONS AND T-TEST OF THE STUDENTS' ATTITUDES IN THE COLLEGES OF EDUCATION IN THE JORDANIAN UNIVERSITIES TOWARDS THE MOBILE PHONE USAGE ATTRIBUTED TO THE ACADEMIC LEVEL

\begin{tabular}{|c|c|c|c|c|c|}
\hline $\begin{array}{c}\text { Academic } \\
\text { level }\end{array}$ & Number & Mean & $\begin{array}{c}\text { Standard } \\
\text { deviation }\end{array}$ & $\begin{array}{c}\text { t- } \\
\text { value }\end{array}$ & $\begin{array}{c}\text { Level of } \\
\text { significance }\end{array}$ \\
\hline Bachelor & 324 & 3.38 & 0.421 & -2.437 & $0.015^{*}$ \\
\hline Master & 39 & 3.55 & 0.415 & & \\
\hline Total & 363 & 3.47 & 0.418 & & \\
\hline
\end{tabular}

*significant at the level $(\alpha \leq 0.05)$

\section{E. Discussion of the results related to the first question}

What are the attitudes of the students in the colleges of education at the Jordanian universities towards the mobile phone usage in university education?

When we study the results related to this question we will find that the percentages are accepted as an indicator of positive attitudes towards mobile phone usage in university education. This result can be interpreted that the students realize the benefits of mobile phone usage in university education and the multi uses and applications due to its great capabilities rendered by mobile phone both in conversation, or SMS, and MMS either in the way of access to information or access to data, and the speed to get it in an interesting way to attract the attention of the students. The student may realize these benefits through exercise and use of mobile phones, both on the black berry and I Phone, etc. or through living with their colleagues who use such phones at the university, or through different mass media. The low positive percentage towards the mobile phone usage in education is attributed to the lack of developed mobile phone with students or to the ignorance of some of them of their applications. This result is consistent with the results of the studies of (Al-Fahad, 2009), (Tenant, 2008), (Waycott and Kuklsca-hulme, 2003) and (Kook, 2007).

\section{F. Discussion of the results related to the second question}

Are there significant statistical differences among the students' attitudes in the colleges of education at the Jordanian universities towards the mobile phone usage attributed to the university of the student (Hashemite University, Yarmouk University, and the University of Jordan)

The results show that there are significant statistical differences at a level $(\alpha \leq 0.05)$ among students' attitudes towards mobile phone usage in university education attributed to the university variable. The differences were between the Hashemite University and the University of Jordan in favor of the Hashemite University, and the reason for this is that the Hashemite University concentrates on e-learning programs. The Hashemite University has founded a special center which takes care of innovations and e-learning technologies at the university and runs on line examinations and e-learning, black board and moodle programs. Besides the successive university administrations may give more attention to concentrate more on the use of this innovation by faculty members and students in different courses may have reflected a little positive effect on the students' attitudes at the Hashemite University towards the mobile phone usage in education more than the students of the University of Jordan.

\section{G. Discussion of the results related to the third question}

Are there significant statistical differences among the students' attitudes in the colleges of education at the Jordanian universities towards the mobile phone usage attributed to gender?

The results show that there are no significant statistical differences among the students' attitudes towards the mobile phone usage in education attributed to gender according to the attitudes scale. This result may be attributed to the equality of the attitudes of both male and female students towards the mobile phone and both genders have the same need to use the mobile phone in university education. Besides their views are identical and that the nature of its use does not constitute a difference between males and females. Besides, the general characteristics of males and females are similar despite the different cultural, social and economical contexts in which they live, reflecting congruent views of both males and females towards the mobile phone usage in university education. This result is consistent with the results of the studies of (Pascler, 2007), (Al-Fahad, 2009), (Tenant, 2008), (Kook, 2007), (and (Dang and Agogino, 2004).

\section{$H$. Discussion of the results related to the fourth ques- tion}

Are there significant statistical differences among the students' attitudes in the colleges of education at the Jordanian universities towards the mobile phone usage attributed to the academic level of the student?

The results of the study show that there are significant statistical differences among the students' attitudes towards the mobile phone usage in university education attributed to the academic level of the student in favor of the master degree students. It seems that the masters students by virtue of their scientific progress and their higher academic level and being more knowledgeable view more positively the mobile phone usage and application in education than the undergraduate students.

\section{RECOMMENDATIONS:}

In the light of the findings of the study, the researchers recommend the following:

- University administrations should design and implement courses to acquaint the students with the mobile phone usage and applications in university education.

- University administrations should spread mobile phone usage literacy in university education because of the positive attitudes of the students towards the use of the mobile.

- Further studies should be conducted on the mobile phone usage in university education covering all levels and majors.

- Further studies are recommended to be conducted on the effect of other variables in the use of mobile in education, such as the grade point average of the student, and the major of the student. 
- Programs should be designed to educate the faculty members and the students about the role of the mobile phone in university education, and to train them how to use it in education so as to have its positive and effective reflection on the students.

\section{REFERENCES}

[1] Abuloum, A., \& Al-Khadash, H., (2005). An analysis of learners, attitudes toward online interaction in a web-based course, Jordan Journal of Educational Science, 1 (2), 155-165

[2] Al-Fahad, F.N. (2009). Students' attitudes and perceptions towards the effectiveness of mobile learning in king Saud University, Saudi Arabia. The Turkish Online Journal of Educational Technology, 8 (2), 111-119.

[3] Al-Omari, A. (2008). Jordanian students' utilization of online instruction and their attitudes towards it. International Journal of Education and Development Using ICT, 4 (2), 1-17.

[4] Al-Qudah, K. (2008). Mobile Phone Ownership and Usage among Students at Jordanian Universities. University of Sharjah Journal for Humanities \& Social Sciences, 5(2), 69-100.

[5] Ascough, R.S. (2002). Designing for online distance education: putting pedagogy before technology. Teaching Theology and Religion. 5 (1) 0.17 to 29.

[6] Cook J., Pachler, N., and Bradley, C. (2008). Bridging the Gap? Mobile Phones at the Interface between Informal and Formal Learning. Accepted by RCET's, special issue: Learning while Mobile. The journal of the research center of education technology, Kent State University, 4 (1), 1-18.

[7] Cook, J. (2007). Generating new learning contexts: novel forms of reuse and learning on the move. Intuited talk at ED-MEDIA 2007-world conference on educational multimedia, Hypermedia \& Tele Communication. June 25-29, Vancouver, Canada.

[8] Dahshan, J. and Younis M. (2009). Education By Mobile Learning "new formula for distance learning." Paper presented to the first scientific symposium of the Department of Comparative Education and Educational Management, College of Education - University of Kafr El-Sheikh under the title of "virtual higher education systems."

[9] Dong, A. \& Agogina, A. M. (2004). In International Conference on Digital Libraries, Vol. 2, the energy and resources institute, New Delhi, pp. 892-898.

[10] Dubendorf, V.A. (2003). Wireless data technology, New York: John Wiley \& Sons. http://dx.doi.org/10.1002/0470861355

[11] Hammamy, M. (2006). Mobile learning a new phase of e-learning. M-Learning-a new stage of E-Learning. The Turkish Online Journal of Educational Technology. Journal of Informatics - Technology in Education, 6, August 2006. Available at: http://infomag.news.sy/index.php?inc=issues/showarticle\&is sueenb $=6 \& i d=70$.

[12] Husain, J., A. (2011): Mobile Learning. Journal of E-Learning \& Renewal Education, 1 (3). PP12-15

[13] Kafafi, W. (2007). Curriculum and to achieving electronic immunity "Future Vision." Paper presented to the Third An- nual Conference "distance education and the knowledge society, the quality requirements and strategies for development." Center for Open Education - Ain Shams University.

[14] Keegan, D. (2010). The Future of Learning, from e-Learning to m-Learning available on line at http://learning.ericsson.net/ (15 November.2010).

[15] Khan, B. (1997). Web-Based Instruction: What is it and why is it?. In B.H. Khan (Ed). Web-based instruction. Englewood Cliffs, NJ "Educational Technology Publication.

[16] Malady, R. \& Argawal, D.P. (2002). Current and future applications of mobile and wireless networks. Communications of the ACM, 45(10), 144-146.

[17] Mcconatha, D. \& Praul, M. (2008). Mobile Learning in Higher Education: An Empirical assessment of a new educational tool. The Turkish Online Journal of Educational Technology, 7 (3), 15-21.

[18] Mohammad, J. \& Al-Karaki, J., Abu-Nab'ah, A. (2008). Analysis of the Members Attitudes towards Using IT Applications in the University Education and its Relation with Some Variables. Journal of Education \& Psychological Sciences.9 (3). PP26-54.

[19] Oreiqat.F., (2003) Students attitudes towards using the internet in learning. A field study on Jordan University higher studies students. Unpublished master thesis, Jordan University. Amman, Jordan.

[20] Pachler, N. (2007). Mobile Learning. WLE Center. London. Elanders Hindson co. ltd.

[21] Salem, A. (2006). Mobile Learning ... a new vision for learning using wireless technologies. Working paper submitted to the Scientific Conference of the Egyptian Society of curricula and teaching methods in the period from July 25 to 26, 2006.

[22] Traxler, J., and Kukulaska-Hulme, A. (2006). Mobile Learning in Developing Countries. Commonwealth of Learning. UK.

[23] Tennant, R. (2008). On the Move with Mobile Web: Library and Mobile Technology. Library Technology Report, July, 44 (5).

[24] Volery, T. (2000). Critical Success Factors in Online Education (Electric Version). The International Journal of Educational Management, 14 (5), 216-223. http://dx.doi.org/10.1108/ 09513540010344731

[25] Waycott, J. \& Kukulska-Hulme, A. (2003). Students' experience with PDAs for Reading Course Materials. Personal and Ubiquitous Computing, 7 (1), 30-43. http://dx.doi.org/10.1007/s00779$\underline{002-0211-\mathrm{X}}$

\section{AUTHORS}

Jebreen A.Hussain and Reem Al Matari are with Hashemite University, Zarqa', Jordan.

Khalid Al-Qudah is with Al al-Bayt University, Mafraq, Jordan.

Received 22 September 2012. Published as resubmitted by the authors 20 March 2013

APPENDIX (1)

ATTITUDES TOWARDS MOBILE PHONE USAGE FOR EDUCATION PURPOSES

\begin{tabular}{|l|l|l|l|l|l|}
\hline \multicolumn{1}{|c|}{ Item } & Strongly agree & agree & unsure & disagree & Strongly disagree \\
\hline $\begin{array}{l}\text { 1. I think it is convenient to use the mobile phone } \\
\text { for educational purposes. }\end{array}$ & & & & & \\
\hline $\begin{array}{l}\text { 2. Mobile phone usage for educational purposes } \\
\text { requires good planning and preparation. }\end{array}$ & & & & & \\
\hline $\begin{array}{l}\text { 3. I want to use the mobile phone technologies for } \\
\text { educational purposes. }\end{array}$ & & & & & \\
\hline $\begin{array}{l}\text { 4. I encourage my colleagues to use the mobile } \\
\text { phone for educational purposes }\end{array}$ & & & & & \\
\hline $\begin{array}{l}\text { 5. I hope that the faculty members communicate } \\
\text { with their students by using the mobile phone for } \\
\text { the educational purposes. }\end{array}$ & & & & & \\
\hline
\end{tabular}




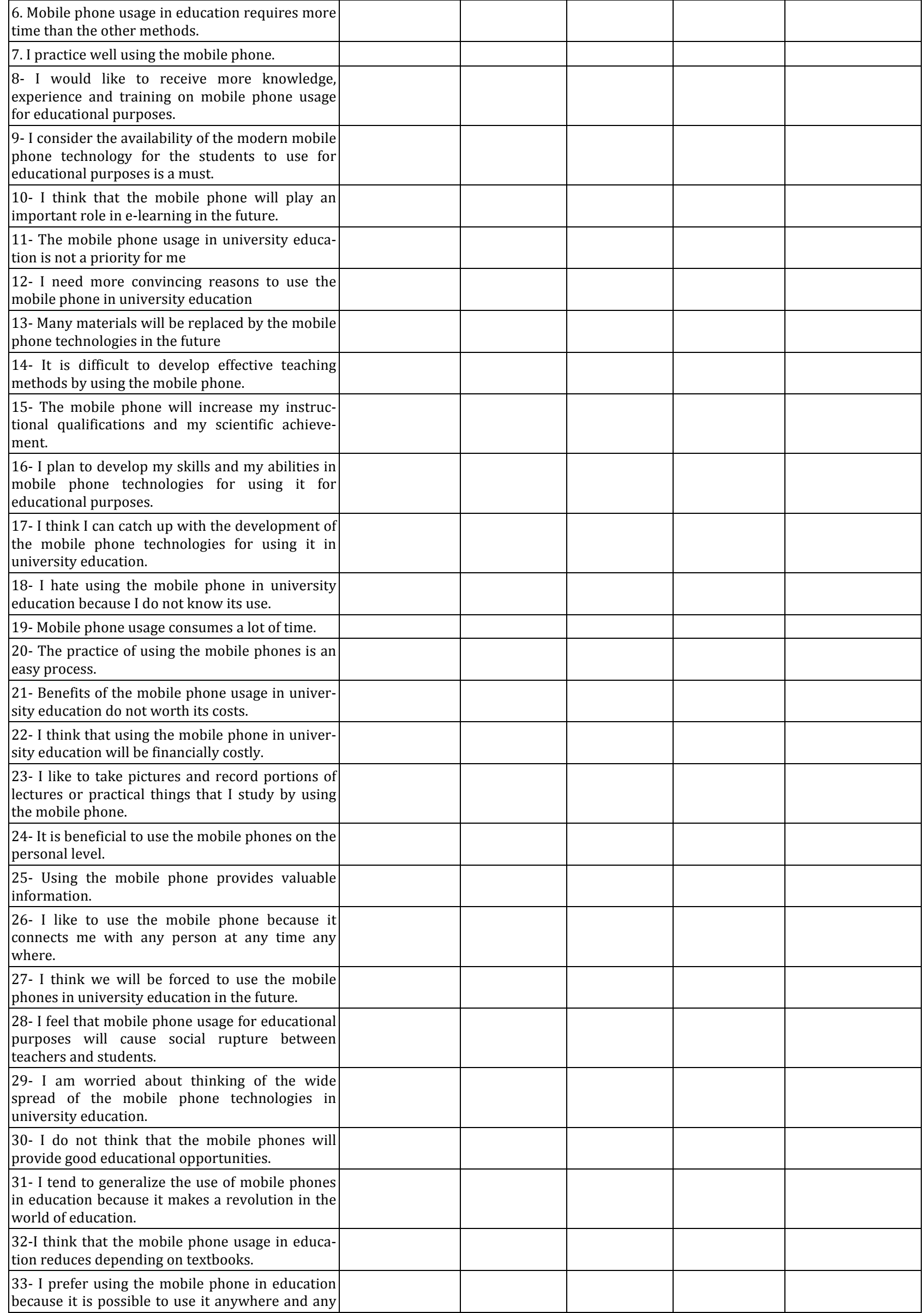




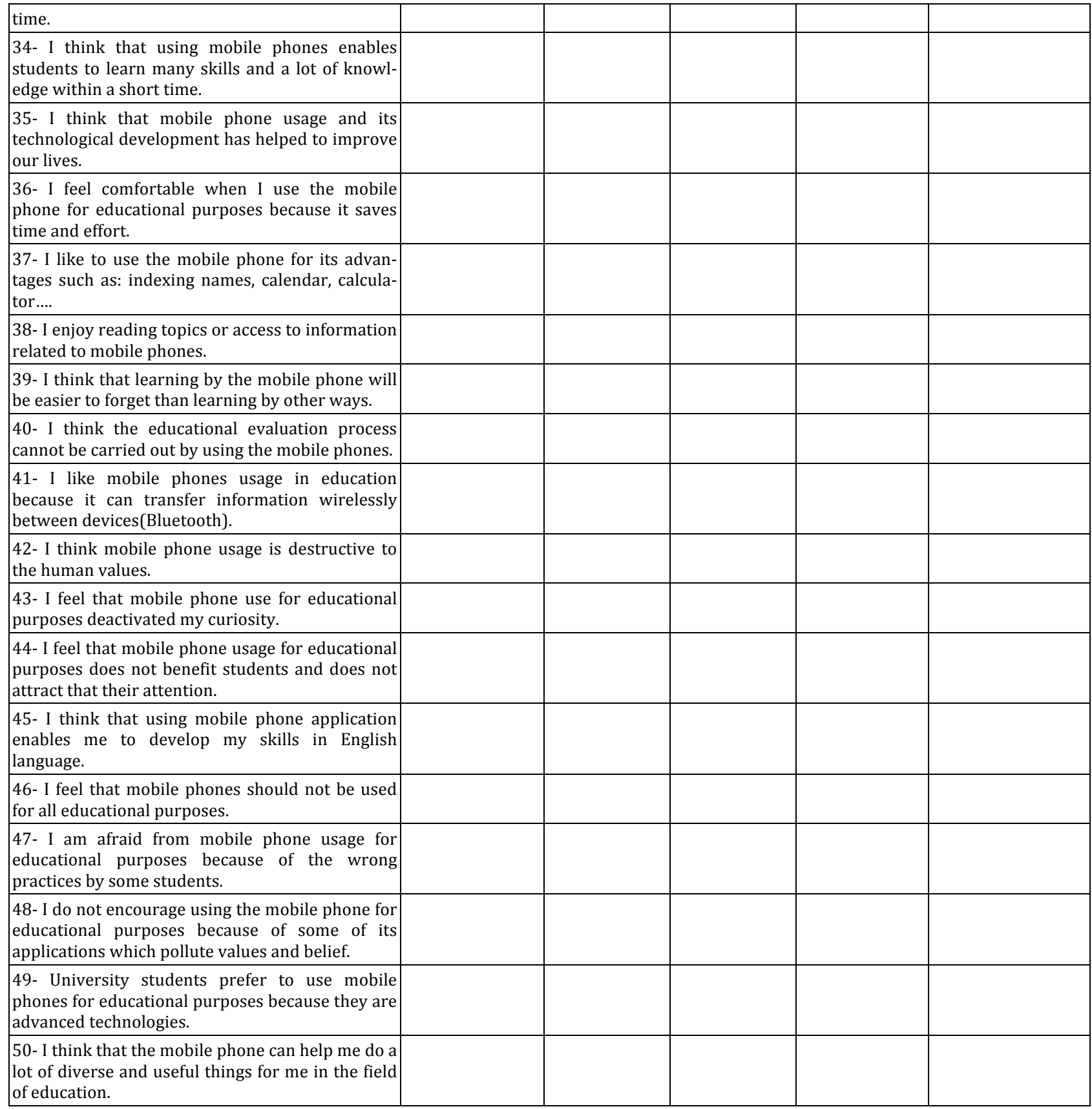

